\title{
BCAR4 wt Allele
}

National Cancer Institute

\section{Source}

National Cancer Institute. BCAR4 wt Allele. NCI Thesaurus. Code C132178.

Human BCAR4 wild-type allele is located in the vicinity of $16 p 13.13$ and is approximately 9 $\mathrm{kb}$ in length. This allele, which encodes breast cancer anti-estrogen resistance 4 long non-coding RNA, plays a role in both metastasis and antiestrogen resistance in breast carcinoma. Focal amplification and chromosomal rearrang ement involving the gene may be associated with cervical cancer. 